\begin{tabular}{l|l} 
Motaice & e-ISSN: 2655-9404 \\
Vol. 2 No. 1, Februari 2019 & DOI: 10.20473/ntr.v2i1.12899 \\
\hline
\end{tabular}

Article history: Submitted 15 December 2018 ; Accepted 8 January 2019; Available online 1 February 2019.

\title{
Penyimpangan Bentuk Upaya Hukum Terhadap Putusan Pailit Akibat PKPU Gagal
}

\author{
Muhammad Pasca Zakky Muhajir Ridlwan \\ luckyjackcattery@gmail.com \\ Universitas Airlangga
}

\begin{abstract}
Article 290 of act number 37 year 2004 about bankruptcy and postponement of debt repayment obligation explain that there is no legal efforts can do for the decision of bankruptcy which is preceded by Suspension of payment. However, in the court practice, the aberration is still being done by the panel of judges in the supreme court judicial review for the decision. The aberration was done by accepting the proposal of judicial review for the bankruptcy case preceded by Suspension of payment which had been decided by commercial court. Amongst of Supreme court decisions Number 48.PK/Pdt.Sus-Pailit/2014 between PT. Surabaya Agung Industrial Pulp \& Kertas combating Asia Base Resources PTE Ltd and The Supreme court Number 156.PK/Pdt.Sus/2012 between Litha \& Co. Firm combating Heryanto Wijaya, PT Bank Negara Indonesia (Persero) Tbk. And PT Sumber Indo Cellular.
\end{abstract}

Keywords: Bankruptcy; Suspension of payment; Final decision.

\begin{abstract}
Abstrak
Pasal 290 Undang-undang No. 37 Tahun 2004 Tentang Kepailitan dan Penundaan Kewajiban Pembayaran Utang pada intinya menerangkan bahwa tidak ada upaya hukum yang dapat dilakukan terhadap putusan pailit yang didahului oleh PKPU. Namun, dalam praktik pengadilan, masih terdapat penyimpangan yang dilakukan oleh Majelis Hakim Peninjauan Kembali Mahkamah Agung terhadap ketentuan tersebut. Penyimpangan tersebut dilakukan dengan menerima pengajuan permohonan peninjauan kembali terhadap perkara kepailitan yang didahului oleh PKPU yang sudah diputus oleh Pengadilan Niaga. Antara lain Putusan Mahkamah Agung No. 48.PK/Pdt.Sus-Pailit/2014 antara PT. Surabaya Agung Industrial Pulp \& Kertas melawan Asiabase Resources PTE Ltd dan Putusan Mahkamah Agung No. 156.PK/Pdt.Sus/2012 antara Firma Litha\&Co melawan Heryanto Wijaya, PT Bank Negara Indonesia (Persero) Tbk. Dan PT. Sumber Indo Cellular.
\end{abstract}

Kata Kunci: Kepailitan; PKPU; Putusan Bersifat Final.

\section{Pendahuluan}

Gejolak moneter yang terjadi pada pertengahan tahun 1997 menimbulkan dampak yang mengkhawatirkan pada kondisi perekonomian. Melemahnya nilai tukar rupiah terhadap mata uang asing telah mengakibatkan terpuruknya dunia usaha. Banyak pengusaha yang tidak mampu untuk mengembangkan usahanya, bahkan hanya untuk mempertahankan usahanya. Pengusaha kesulitan untuk membayar utang terutama kepada kreditor luar negeri. Disamping itu, kredit macet 
di perbankan dalam negeri angkanya semakin tinggi. ${ }^{1}$

Kompleksitas permasalahan yang dialami ternyata tidak didukung oleh pranata hukum yang memadai. Kebutuhan hukum tersebut tercermin dalam bagian menimbang Undang-Undang Nomor 4 Tahun 1998 tentang Penetapan Perppu Nomor 1 Tahun 1998 tentang Perubahan atas Undang-Undang tentang Kepailitan menjadi UndangUndang yang menjelaskan penyelesaian utang piutang di kalangan dunia usaha, besar artinya dalam upaya pemulihan kegiatan usaha pada khususnya dan perkembangan perekonomian pada umumnya, sedang dalam Undang-Undang tentang Kepailitan (faillissements-veronding yang diundangkan dalam Staatsblad Tahun 1905 Nomor 217 jo Staatsblad Tahun 1906 Nomor 348) sebagian besar tidak sesuai lagi dengan perkembangan keadaan, maka perlu dilakukan perubahan atas Undang-Undang tentang Kepailitan tersebut. Namun perubahan tersebut ternyata belum mampu mengakomodir perkembangan dan kebutuhan hukum masyarakat. Oleh karena itu, diterbitkanlah Undang-Undang Nomor 37 Tahun 2004 tentang Kepailitan dan Penundaan Kewajiban Pembayaran Utang, Selanjutnya disebut sebagai UUK-PKPU. PKPU merupakan keistimewaan yang diberikan oleh Undang-Undang kepada debitor untuk bermusyawarah kembali. Ada proses perdamaian yang dilakukan dan diharapkan tidak sampai kepada tahap pailit. Oleh karena itu, PKPU dapat pula disebut sebagai upaya hukum yang berdiri sendiri, selain upaya hukum kepailitan.

Proses perdamaian yang dilakukan para pihak beserta Pengurus dan Hakim Pengawas memiliki dua kemungkinan. Pertama, perdamaian disepakati dan disampaikan oleh Hakim Pengawas kepada Majelis untuk disahkan. Akan tetapi apabila debitor telah diberikan kesempatan oleh kreditor untuk menyelesaikan kewajibannya melalui jalan PKPU masih tetap tidak mampu menyelesaikan kewajiban utangnya, maka kreditor mengajukan permohonan kepada Majelis Hakim Pengadilan Niaga agar debitor dijatuhi putusan pailit sehingga debitor dipaksa untuk menyelesaikan kewajibannya tersebut dengan cara mengambil dari harta kekayaan debitor.

${ }^{1}$ Sutan Remy Sjahdeini, Hukum Kepailitan: Memahami Undang-Undang Nomor 37 Tahun 2004 Tentang Kepailitan (Pustaka Utama Grafiti 2009).[22]. 
Kedua, Pengakhiran PKPU, karena tidak tercapainya perdamaian, maka berakibat debitor PKPU dinyatakan pailit oleh pengadilan. Atas putusan pailit yang berasal atau didahului dengan PKPU itu tidak dapat ditempuh upaya hukum sebagaimana diatur dalam Pasal 290 UUK-PKPU yang mengatur "apabila Pengadilan telah menyatakan debitor pailit, maka terhadap putusan pernyataan pailit tersebut berlaku ketentuan tentang kepailitan sebagaimana dimaksud dalam Bab II, kecuali Pasal 11, Pasal 12, Pasal 13 dan Pasal 14”.

Namun, dalam praktik, beberapa kali terjadi penyimpangan terhadap UndangUndang tersebut. Pihak yang merasa dikalahkan oleh putusan Pengadilan Niaga mengajukan upaya hukum kasasi ke Mahkamah Agung. Sebagaimana terdapat dalam putusan Perkara Nomor 48.PK/Pdt.Sus-Pailit/2014 antara PT. Surabaya Agung Industrial Pulp \& Kertas melawan Asiabase Resources PTE Ltd dan putusan Perkara Nomor 156.PK/Pdt.Sus/2012 antara Firma Litha\&Co melawan Heryanto Wijaya, PT. Bank Negara Indonesia (Persero) Tbk. Dan PT. Sumber Indo Cellular.

Berdasarkan uraian di atas, maka dapat dirumuskan beberapa permasalahan pokok yang diteliti yaitu ratio legis Undang-Undang Nomor 37 Tahun 2004 tentang Kepailitan menentukan bahwa terhadap putusan pailit yang berasal dari PKPU tidak dapat dilakukan upaya hukum dan ratio decidendi putusan yang membolehkan upaya hukum putusan pailit yang berasal dari PKPU.

\section{Metodologi Penelitian}

Penelitian hukum (legal research) adalah suatu proses untuk memecahkan isu hukum yang dihadapi dengan cara mengidentifikasi masalah hukum, melakukan penalaran hukum, menganalisis masalah yang dihadapi kemudian memberikan pemecahan atas masalah tersebut. ${ }^{2}$

Penelitian doktrinal atau doctrinal research, yaitu penelitian terhadap peraturan perUndang-Undangan maupun literatur yang berkaitan dengan materi yang dibahas dengan menyediakan penjelasan secara sistematis mengenai norma-norma hukum

\footnotetext{
${ }^{2}$ Peter Mahmud Marzuki, Penelitian Hukum (Kencana Prenada Media 2014).[60].
} 
yang menjadi suatu kategori tertentu dan menganalisa hubungan antara norma hukum, menjelaskan bidang-bidang yang sulit dan diharapkan memberi prediksi perkembangan norma tersebut kedepannya.

Penelitian teoritik atau theoretical research adalah penelitian yang berusaha menggali pemahaman yang lebih komplit mengenai akibat-akibat yang timbul dari sedemikian banyaknya aturan dan prosedur hukum yang mengatur sebuah bidang aktifitas tertentu.ini bertujuan untuk memproleh dasar dari asas-asas yang berkembang dalam masyarakat.

Metode pendekatan masalah yang digunakan yaitu statute Approach (pendekatan peraturan perundang-undangan), yaitu pendekatan yang dilakukan dengan menelaah semua peraturan perundang-undangan terkait dan regulasi lainnya yang bersangkut paut dengan isu hukum yang sedang ditangani. ${ }^{3}$ Conseptual Approach yaitu pendekatan yang dilakukan dengan mempelajari pandanganpandangan dan doktrin-doktrin di bidang ilmu hukum. ${ }^{4}$ Case Approach yaitu pendekatan terhadap rumusan masalah melalui kasus yang ada di dunia kerja yang berkaitan dengan topik yang di bahas. ${ }^{5}$

\section{Ratio Legis Tidak Dapat Dilakukan Upaya Hukum Terhadap Putusan Pailit Yang Berasal Dari PKPU}

Berlakunya UUK-PKPU memberikan harapan dalam rezim hukum kepailitan. Terutama mengenai pembatasan pengertian utang, jatuh waktu dan juga hukum acara kepailitan. Persyaratan yang harus dipenuhi untuk mengajukan permohonan pailit yaitu terdapat dua atau lebih kreditor dan tidak membayar lunas sedikitnya satu utang yang jatuh waktu dan dapat ditagih.

Terhadap ketentuan tersebut, menarik untuk diperhatikan pertimbangan hakim Mahkamah Konstitusi dalam Putusan Mahkamah Konstitusi Nomor: 071/ PUU-II/2004 dan Nomor: 001-002/PUU-III/2005 yang mengatur:

\footnotetext{
${ }^{3}$ ibid. [93].

${ }^{4}$ ibid. [95].

${ }^{5}$ ibid. [94].
} 
Mahkamah berpendapat bahwa persyaratan yang sangat longgar untuk mengajukan permohonan pernyataan pailit merupakan kelalaian pembuat Undang-Undang dalam merumuskan Pasal 2 ayat (1) tersebut karena jika dibandingkan misalnya dengan ketentuan yang terdapat dalam Pasal 1 ayat (1) Faillissement-Verordening (Stb. 05-217 jo 06-348) yang berbunyi "De schuldenaar, die in den toestand verkeert dat hij heeft opgehouden te betalen, wordt, hetzij op eigen aangifte, hetzij op verzoek van een of meer zijner schuldeischers, bij rechterlijk vonnis in staat van faillissement verklaard", maka Frasa "hij heeft opgehouden te betalen" (keadaan tidak mampu membayar) ternyata tidak terdapat dalam rumusan Pasal 2 ayat (1) UndangUndang a quo. Dengan tiadanya persyaratan "tidak mampu membayar", maka kreditor dapat dengan mudah mengajukan permohonan pernyataan pailit terhadap perusahaan asuransi tanpa harus membuktikan bahwa perusahaan asuransi itu dalam keadaan tidak mampu membayar. Sebagai perbandingan lain, dalam Title II Unites States Bankruptcy Code 1994 yang diperbarui tahun 1998 persyaratan "dalam keadaan tidak mampu membayar" yang dikenal dengan istilah "insolvent" merupakan salah satu syarat dari permohoan pernyataan pailit.

Dalam Bankruptcy Code tersebut insolvent diartikan antara lain sebagai, “..... financial condition that the sum of such entity's debts is greater than all of such entity's property"; "unable to pay its debts as they become due". Bahwa dengan adanya persyaratan itu, maka pernyataan pailit harus didahului oleh pengujian apakah benar seorang debitor telah dalam keadaan tidak mampu membayar (insolvency test), justru hal tersebut tidak tercantum dalam rumusan Pasal 1 Undang-Undang a quo. ${ }^{6}$

Namun, Mahkamah Konstitusi yang terkadang mengambil kewenanangan sebagai negative legislature, dalam hal ini tidak menggunakan kewenangannya untuk merubah ketentuan tersebut. Meskipun pada dasarnya memang tidak diajukan oleh Pemohon. Oleh karena itu, ketentuan tersebut masih berlaku sebagaimana adanya.

Persyaratan pertama yang harus dipenuhi adalah adanya dua kreditor atau lebih. Adanya dua kreditor atau lebih erat kaitannya dengan beberapa prinsip hukum dalam rezim hukum kepailitan yaitu pari passu prorata parte dan structured creditors. Implementasi dari prinsip hukum tersebut terdapat dalam Pasal 1132 BW. Pembagian secara proporsional harta kekayaan milik debitor tersebut menggunakan prinsip structured creditors yang berarti ada kreditor yang harus didahulukan. Penjelasan Pasal 2 ayat (1) UUK-PKPU mengatur:

${ }^{6}$ Putusan Mahkamah Konstitusi Nomor: 071/PUU-II/2004 dan Nomor: 001-002/PUU$\mathrm{III} / 2005$ 
Yang dimaksuddengan"Kreditor" dalamayatini adalahbaik kreditorkonkuren, kreditor separatis, maupun kreditor preferen. Khusus mengenai kreditor separatis dan kreditor preferen, mereka dapat mengajukan permohonan pailit tanpa kehilangan hak agunan atas kebendaan yang mereka miliki terhadap harta debitor dan haknya untuk didahulukan. Bilamana terdapat sindikasi kreditor maka masing-masing kreditor sebagaimana dimaksud dalam Pasal 1 angka 2 .

Kreditor konkuren adalah kreditor yang memiliki kedudukan yang sama dengan kreditor lainnya. Dalam artian bahwa ketika terjadi pembagian maka disesuaikan dengan besaran tagihan kreditor. Kreditor istimewa menurut Sutan Remy Sjahdeini adalah:

Hak Istimewa (piutang yang diistimewakan) yang oleh Undang-Undang harus didahulukan daripada piutang atas tagihan yang dijaminkan dengan hak jaminan antara lain adalah:

1. Hak Istimewa yang dimaksudkan dalam Pasal 1137 ayat (1) KUH Perdata;

2. Hak Istimewa yang dimaksudkan dalam ayat (3) Pasal 21 UU Nomor 6 Tahun 1983 tentang Ketentuan Umum dan Tata Cara Perpajakan yang telah diubah dengan UU Nomor 9 Tahun 1994;

3. Hak Istimewa yang dimaksudkan dalam Pasal 1139 ayat (1) KUH Perdata yaitu, biaya perkara yang semata-mata disebabkan karena suatu penghukuman untuk melelang suatu benda bergerak atau benda tidak bergerak;

4. Hak Istimewa yang dimaksudkan dalam Pasal 1149 angka (1) KUH Perdata, yaitu biaya-biaya perkara yang semata-mata disebabkan karena pelelangan dan penyelesaian suatu warisan;

5. Imbalan kurator sebagaimana dimaksud dalam UU Nomor 37 Tahun $2004 .^{7}$

Lebih lanjut, Sutan Remy Sjahdeini menjelaskan Hak Separatis adalah hak yang diberikan oleh hukum kepada kreditor pemegang hak jaminan bahwa barang jaminan (agunan) yang dibebani dengan hak jaminan (menurut istilah yang dipakai dalam UU Nomor 4 Tahun 1998 dan UUK-PKPU ialah hak agunan) tidak termasuk harta pailit. ${ }^{8}$

Persyaratan kedua yang harus dipenuhi adalah adanya utang yang jatuh waktu dan dapat ditagih. Utang merupakan kewajiban yang dapat dinyatakan dalam bentuk uang yang meliputi segala prestasi sebagaimana diatur dalam Pasal 1234 BW. Sutan Remy Sjahdeini menambahkan bahwa claim menurut Bankruptcy

\footnotetext{
7 Sutan Remy Sjahdeini (n 1).Op.Cit.[6].

8 ibid.[45].
} 
Code Amerika mengharuskan adanya right to payment..$^{9}$ Tanpa itu, maka kewajiban debitor tersebut tidak dapat dianggap sebagai claim. Pasal 1 Angka 6 UndangUndang Nomor 37 Tahun 2004 mengatur:

Utang adalah kewajiban yang dinyatakan atau dapat dinyatakan dalam jumlah uang baik dalam mata uang Indonesia maupun mata uang asing, baik secara langsung maupun yang akan timbul di kemudian hari atau kontingen, yang timbul karena perjanjian atau Undang-Undang dan wajib dipenuhi oleh debitor dan bila tidak dipenuhi memberi hak kepada kreditor untuk mendapat pemenuhannya dari harta kekayaan debitor.

Untuk terpenuhinya persyaratan pailit, debitor tidak hanya mempunyai utang, tetapi juga tidak membayar lunas satu utang yang jatuh waktu dan dapat ditagih. Apabila dikaitkan dengan persyaratan dua atau lebih kreditor, maka permohonan pailit hanya mempersyaratkan tidak adanya pembayaran lunas utang kepada satu kreditor. M. Hadi Subhan menyatakan:

Sedangkan maksud dari ditegaskannya bahwa utang dalam kepailitan merupakan utang yang tidak dibayar lunas adalah untuk memastikan bahwa utang yang telah dibayar akan tetapi belum melunasi kewajiban maka utang tersebut bisa dijadikan dasar untuk mengajukan kepailitan. Penegasan ini karena sering terjadi akal-akalan dari debitor, yakni, debitor tetap melakukan pembayaran tetapi besarnya angsuran pembayaran tersebut masih jauh dari yang seharusnya. ${ }^{10}$

Apabila kedua persyaratan tersebut terpenuhi, debitor dapat dinyatakan pailit, baik atas permohonannya sendiri, maupun atas permohonan satu atau lebih kreditornya. Agar tidak dinyatakan pailit, debitor dapat mengajukan PKPU. Atau kreditor yang tidak ingin debitor pailit dikarenakan beberapa hal, kreditor juga dapat mengajukan PKPU.

Selain kepailitan, sebenarnya terdapat pranata hukum lain yang dapat menyelesaikan permasalahan tersebut, yaitu PKPU. Dalam hukum dagang dikenal

\footnotetext{
${ }^{9}$ Sutan Remy Sjahdeini, Sejarah, Asas, Dan Teori Hukum Kepailitan, Memahami Undang-Undang Nomor 37 Tahun 2004 Tentang Kepailitan Dan Penundaan Kewajiban Pembayaran Utang (Kencana Prenada Media 2016).[105].

${ }^{10}$ M. Hadi Subhan, Hukum Kepailitan; Prins.Ip, Norma, Dan Praktik Di Peradilan (Kencana Prenada Media 2008).[92].
} 
dengan istilah serseance van betailing atau suspension of payment. ${ }^{11}$ Lebih lanjut, Zainal Asikin menjelaskan:

Dalam kasus PKPU, debitor berada dalam keadaan sulit untuk dapat memenuhi (membayar) utangnya secara penuh. Tetapi, kesulitan itu belumlah menjadi indikasi ke arah kebangkrutan (kepailitan). Apabila debitor diberi waktu, ia akan sanggup (mampu) memenuhi atau melunasi utangnya secara penuh. Maka dari itu, debitor dapat memohon PKPU dengan tujuan agar ia bisa memperbaiki ekonomi dan perusahaan yang terjebak dalam kesulitan ekonomi tersebut. ${ }^{12}$

Sutan Remy Sjahdeiny menyatakan PKPU pada hakikatnya bertujuan mengadakan perdamaian antara debitor dengan para kreditornya menghindarkan debitor yang telah atau akan mengalami insolven dari kepailitan. ${ }^{13}$

UUK-PKPU tidak memberikan definisi mengenai apa yang disebut dengan PKPU, baik dalam batang tubuh maupun penjelasan. Pasal 222 ayat (1) UUK-PKPU hanya menjelaskan bahwa PKPU diajukan oleh debitor yang mempunyai lebih dari 1 (satu) kreditor atau lebih. Ketentuan ini kalau tidak dibaca secara seksama, dapat menimbulkan multitafsir. Hal ini dikarenakan terdapat kalimat "diajukan oleh debitor" yang dapat dimaknai bahwa pemohon PKPU hanya dapat dilakukan oleh debitor sebagaimana diatur dalam Undang-Undang Nomor 4 Tahun 1998 sebelum diganti dengan Undang-Undang Nomor 37 Tahun 2004. Pasal 212 Undang-Undang Nomor 4 Tahun 1998 yang mengatur:

Debitor yang tidak dapat atau memperkirakan bahwa ia tidak akan dapat melanjutkan membayar utang-utangnya yang sudah jatuh waktu dan dapat ditagih, dapat memohon PKPU, dengan maksud pada umumnya untuk mengajukan rencana perdamaian yang meliputi tawaran pembayaran seluruh atau sebagian utang kepada kreditor konkuren.

Padahal, dalam konteks UUK-PKPU yang dapat mengajukan permohonan PKPU tidak hanya debitor, melainkan juga kreditor. Pasal 222 ayat (2) dan ayat (3) UUK-PKPU mengatur:

\footnotetext{
${ }^{11}$ Victor Simamorang dan Hendri Sukarso, Pengantar Hukum Kepailitan Di Indonesia (Rineka Cipta 1994).[130].

${ }^{12}$ Zainal Asikin, Hukum Kepailitan Dan Penundaan Pembayaran Di Indonesia (Raja Grafindo Persada 2001).[83].

${ }^{13}$ Sutan Remy Sjahdeini (n 1).Op.Cit.[328].
} 
(1) Debitor yang tidak dapat atau memperkirakan tidak akan dapat melanjutkan membayar utang-utangnya yang sudah jatuh waktu dan dapat ditagih, dapat memohon PKPU, dengan maksud untuk mengajukan rencana perdamaian yang meliputi tawaran pembayaran sebagian atau seluruh utang kepada kreditor.

(2) Kreditor yang memperkirakan bahwa debitor tidak dapat melanjutkan membayar utangnya yang sudah jatuh waktu dan dapat ditagih, dapat memohon agar kepada debitor diberi PKPU, untuk memungkinkan debitor mengajukan rencana perdamaian yang meliputi tawaran pembayaran sebagian atau seluruh kepada kreditornya.

Pada prinsipnya, baik kepailitan maupun PKPU tujuan utamanya adalah menyelesaikan permasalahan utang piutang antara debitor dengan kreditor. Adanya kepailitan dan PKPU itu bersumber dari adanya ketidakmampuan atau diperkirakan tidak mampunya debitor untuk menyelesaikan kewajiban berupa pembayaran utang. Pelembagaan kepailitan dan PKPU semata-mata untuk menghindari adanya itikad tidak baik dari debitor untuk tidak membayar utangnya, kreditor dalam penagihan piutangnya maupun persaingan diantara para kreditor untuk mendapatkan pembayaran atas piutangnya.

Apabila permohonan PKPU diajukan pada waktu yang bersamaan atau setelah adanya permohonan pailit, permohonan PKPU harus diputus terlebih dahulu. Pasal 229 ayat (3) dan ayat (4) UUK-PKPU mengatur:

(3) Apabila permohonan pernyataan pailit dan permohonan PKPU diperiksa pada saat yang bersamaan, permohonan PKPU harus diputuskan terlebih dahulu.

(4) Permohonan PKPU yang diajukan setelah adanya permohonan pernyataan pailit yang diajukan terhadap debitor, agar dapat diputus terlebih dahulu sebagaimana dimaksud pada ayat (3), wajib diajukan pada sidang pertama pemeriksaan permohonan pernyataan pailit.

Ketentuan tersebut menjelaskan bahwa permohonan PKPU harus diajukan pada sidang pertama pemeriksaan permohonan pernyataan pailit. Putusan atas permohonan PKPU apabila diajukan setelah permohonan pailit harus diterbitkan terlebih dahulu.

Terhadap putusan pailit yang didahului oleh PKPU tidak dapat diajukan upaya hukum apapun. Sebagaimana diatur dalam Pasal 290 UUK-PKPU yang mengatur apabila Pengadilan telah menyatakan Debitor pailit maka terhadap putusan 
pernyataan pailit tersebut berlaku ketentuan tentang kepailitan sebagaimana dimaksud dalam Bab II, kecuali Pasal 11, Pasal 12, Pasal 13, dan Pasal 14. Pasalpasal yang dikecualikan tersebut mengatur mengenai mekanisme upaya hukum.

Akhir dari suatu upaya hukum yang dilakukan melalui lembaga peradilan adalah terbitnya putusan. Setelah memeriksa dan/atau mendengarkan para pihak disertai dengan berbagai bukti yang dihadirkan di pengadilan, hakim akan menyimpulkan suatu permasalahan melalui putusan.

Dalam sistem hukum Indonesia, disediakan pranata untuk melakukan upaya hukum, baik upaya hukum biasa maupun upaya hukum luar biasa. Upaya hukum biasa adalah perlawanan terhadap putusan pengadilan tingkat pertama melalui banding, pengadilan tingkat kedua melalui kasasi. Sedangkan upaya hukum luar biasa adalah perlawanan terhadap putusan kasasi Mahkamah Agung melalui peninjauan kembali.

Putusan kasasi ini biasanya disebut dengan putusan yang mempunyai kekuatan hukum mengikat. Meskipun tidak menutup kemungkinan bahwa putusan yang mempunyai kekuatan hukum mengikat bisa berasal dari setiap tingkatan lembaga peradilan. Pada prinsipnya, putusan pengadilan yang itu didahului oleh PKPU tidak dapat dilakukan upaya hukum. Terdapat pengecualian apabila diatur lain dalam undang undang tersebut. Pasal 293 ayat (1) UUK-PKPU mengatur terhadap putusan pengadilan berdasarkan ketentuan dalam Bab III ini tidak terbuka upaya hukum, kecuali ditentukan lain dalam Undang-Undang ini. Terdapat pengecualian pengaturan upaya hukum terhadap putusan pailit yang didahului PKPU. Pengecualian tersebut terkait dengan pengakhiran PKPU sebagaimana diatur dalam Pasal 266 ayat (1) UUK-PKPU. Terhadap putusan tersebut masih disediakan upaya hukum kasasi dan peninjauan kembali. Alasan yang digunakan untuk pengakhiran PKPU sebagaimana diuraikan diatas lebih kondisi debitor, harta kekayaan debitor, dan tidak adanya itikad baik dari debitor. Selain itu, tidak disediakan upaya hukum apapun untuk putusan pailit yang didahului oleh PKPU atau bersifat final.

Namun dalam praktik peradilan, penerapan Pasal 290 UUK-PKPU masih sering disimpangi. Masih banyak putusan pailit yang didahului oleh PKPU yang 
diajukan upaya hukum berupa peninjauan kembali. Berbagai pertimbangan hukum digunakan sebagai alasan untuk menerima upaya hukum peninjauan kembali tersebut. Bahkan Mahkamah Agung sampai mengeluarkan Surat Edaran Mahkamah Agung Nomor 3 Tahun 2015 tentang Pemberlakuan Rumusan Hasil Rapar Pleno Kamar Mahkamah Agung Tahun 2015 Sebagai Pedoman Pelaksanaan Tugas Bagi Pengadilan dalam Praktik Peradilan. Surat Edaran Mahkamah Agung tersebut pada bagian rumusan kamar hukum perdata menyatakan:

tidak ada upaya hukum apapun terhadap:

1. Putusan PKPU Sementara (Pasal 235);

2. Putusan PKPU Tetap (Pasal 235);

3. Putusan PKPU Tetap tidak disetujui oleh kreditor, kemudian debitor dinyatakan pailit (Pasal 290);

4. Putusan penolakan perdamaian dalam PKPU (Pasal 285 ayat (4));

5. Putusan atas permohonan Rehabilitasi terhadap Debitor (ahli waris) setelah berakhirnya kepailitan (Pasal 220).

Jika terhadap putusan kepailitan/PKPU yang tidak tersedia upaya hukum apapun sebagaimana dimaksud dalam huruf $b$ di atas tetap diajukan ke MA, maka isi amar putusan adalah TIDAK DAPAT DITERIMA.

\section{Kasus Posisi Putusan Mahkamah Agung No. 48.PK/Pdt.Sus-Pailit/2014}

Asiabase Resources PTE, Ltd., (selanjutnya disebut sebagai Pemohon) mengajukan permohonan PKPU terhadap PT. Surabaya Agung Industri Pulp \& Kertas (selanjutnya disebut sebagai Termohon). Permohonan tersebut dikarenakan adanya perjanjian antara Pemohon dengan Termohon mengenai jual beli bahan baku produksi berupa bubur kertas (pulp) selama periode 9 Juni 2010 dan 24 Juni 2010. Berdasarkan perjanjian tersebut, Pemohon telah mengirimkan barang sebagaimana telah diperjanjikan. Namun, Termohon belum melakukan pembayaran terhadap barang yang sudah dikirim dengan rincian sebagai berikut:

- Invoice Nomor 016 (A)/EPPCO 9 Jun 2010 total tagihan USD230,689.37, total pembayaran USD80,000.00, sisa pembayaran USD150,689.37;

- Invoice Nomor 016(A)-1/EPPCO24 Jun 2010 total tagihan USD167,615.18, total pembayaran USD 0, sisa pembayaran USD167,615.18;

- Interest (bunga) USD97,731.29 (Oktober 2010 sampai dengan Juni 2013).

Dengan demikian maka total kewajiban Termohon PKPU kepada 
Pemohon PKPU yang telah jatuh tempo dan dapat ditagih seluruhnya berjumlah USD415,035.84 (empat ratus lima belas ribu tiga puluh lima koma delapan puluh empat sen Dollar Amerika);

Terhadap utang tersebut, Pemohon telah meminta kepada Termohon untuk melaksanakan kewajiban membayar utang. Bahkan sampai mengirimkan somasi pada tanggal 11 Februari 2013 melalui surat Nomor 100/HP-HS/II/2013. Selain kepada Pemohon, Termohon juga memiliki kewajiban membayar utang kepada :

1. Sanyi Resources PTE. LTD, berkedudukan di 10 Jalan Besar \# 11-12 SIM LIM Tower Singapore (208787) dengan perincian jumlah piutang yaitu sebagai berikut:

$>$ Total Tagihan : USD 410,968.69;

$>$ Total Pembayaran : USD 130,000.00;

$>$ Bunga Keterlambatan : USD 90,939.59;

Sisa Tagihan Tertunggak : USD 371,908.28;

2. Inter Fiberasia PTE. LTD, berkedudukan di 10 Anson Road \# 11-13 International Plaza Singapore (079903) dengan perincian jumlah piutang yaitu sebagai berikut:

$>$ Total Tagihan : USD 30,427.74;

$>$ Total Pembayaran : USD 0;

$>$ Bunga Keterlambatan : USD 16,209.35;

Sisa Tagihan Tertunggak : USD 46.637.09;

Namun, Pemohon memperkirakan Termohon memiliki kemampuan untuk melakukan pembayaran utang apabila dilihat dari asset yang dimiliki Termohon dan/atau milik pihak ketiga dalam kapasitasnya debagai penjamin/penanggung, berikut aktivitas-aktivitas usaha yang dilakukan Termohon.

Berdasarkan permohonan tersebut, pada tanggal 5 Maret 2013, Pengadilan Niaga pada Pengadilan Negeri Surabaya mengeluarkan Putusan Nomor 01/ PKPU/2013/ PN Niaga Sby. yang amar putusannya sebagai berikut:

1. Mengabulkan permohonan PKPU Sementara dari Pemohon PKPU selama 45 hari terhitung sejak tanggal putusan diucapkan;

2. Menunjuk Sdr. Sriyatmo Joko Sungkowo, S.H., Hakim Niaga pada Pengadilan Niaga Surabaya sebagai Hakim Pengawas; 
3. Mengangkat Sdr. Drs. Joko Prabowo, S.H., M.H., Pengurus dan Kurator, yang terdaftar di Departemen Hukum dan Hak Asasi Manusia dibawah Nomor AHU.AH.04.03-67 tertanggal 20 Juni 2012 yang berkedudukan di Siadari \& Partners, Gedung Manggala Wanabakti, Blok IV, 7th Floor, Room 718, Jalan Jend. Gatot Subroto, Jakarta Pusat 10270 dan Sdr. Jandri Siadari, S.H., LL.M., Pengurus dan Kurator, yang terdaftar di Departemen Hukum dan Hak Asasi Manusia dibawah Nomor AHU.AH.04.03-65 tertanggal 31 Juli 2008 yang berkedudukan di Siadari \& Partners, Gedung Manggala Wanabakti, Blok IV, 7th Floor, Room 718, Jalan Jend. Gatot Subroto. Jakarta Pusat 10270 sebagai pengurus dalam perkara PKPU atas PT Surabaya Agung Industri Pulp \& Kertas;

4. Menetapkan bahwa hari sidang berikutnya pada Hari Selasa Tanggal 16 April 2013 bertempat di Pengadilan Negeri/Niaga Surabaya di Jalan Raya Arjuno Nomor 18 Surabaya;

5. Memerintahkan Pengurus untuk memanggil para Kreditor yang dikenal dalam surat tercatat agar datang pada sidang yang telah ditetapkan diatas,

6. Menetapkan biaya pengurusan dan imbalan jasa bagi pengurus akan ditetapkan kemudian setelah PKPU berakhir;

7. Menangguhkan biaya permohonan PKPU ini sampai dengan PKPU dinyatakan selesai.

Sebagai tindak lanjut putusan tersebut, diadakan pertemuan yang intinya menerangkan mengenai penolakan perpanjangan PKPU. Hakim Pengawas dan Pengurus membacakan laporan mengenai hasil dari pertemuan sebagaimana diuraikan sebelumnya, pada hari Selasa, 16 April 2013 dalam sidang pemeriksaan atas pelaksanaan putusan Majelis Hakim yang memberikan PKPU Sementara. Dalam sidang tersebut pula didengar keterangan dari kreditor dan juga Pemohon.

Berdasarkan alasan hukum tersebut, Majelis Hakim Pengadilan Niaga pada Pengadilan Negeri Surabaya mengeluarkan putusan Nomor 01/PKPU/2013/ PN Niaga Sby. tanggal 16 April 2013, yang amar putusannya mengatur:

1. Menolak rencana perdamaian yang diajukan Termohon PKPU tersebut:

2. Menyatakan Termohon PKPU PT Surabaya Agung Industri Pulp \& Kertas Pailit dengan segala akibat hukumnya;

3. Menunjuk Sdr. Sriyatmo Joko Sungkowo, S.H. Hakim Niaga pada Pengadilan Niaga Surabaya sebagai Hakim Pengawas;

4. Mengangkat:

1. Sdr. Drs. Joko Prabowo, S.H.,M.H., Pengurus dan Kurator, yang terdaftar di Departemen Hukum dan Hak Asasi Manusia dibawah Nomor AHU. AH.04.03-67 tertanggal 20 Juni 2012 yang berkedudukan di Siadari \& Partners, Gedung Manggala Wanabakti, Blok IV, 7th Floor, Room 718, Jalan Jend. Gatot Subroto, Jakarta Pusat 10270; 
2. Sdr. Jandri Siadari, S.H., LL.M., Pengurus dan Kurator, yang terdaftar di Departemen Hukum dan Hak Asasi Manusia dibawah Nomor AHU. AH.04.03-65 tertanggal 31 Juli 2008 yang berkedudukan di Siadari \& Partners, Gedung Manggala Wanabakti, Blok IV. 7th Floor, Room 718, Jalan Jend. Gatot Subroto, Jakarta Pusat 10270; Bersama-sama sebagai tim kurator PT Surabaya Agung Industri Pulp \& Kertas;

5. Menyatakan biaya kepalitan dan imbalan jasa bagi Kurator akan ditetapkan kemudian setelah proses kepailitan berakhir;

6. Membebankan biaya permohonan kepada Pemohon sampai saat ini sebesar Rp4.186.000,00;

Termohon mengajukan permohonan Peninjauan Kembali terhadap putusan tersebut di Kepaniteraan Pengadilan Negeri/Niaga Surabaya pada tanggal 11 Oktober 2013. Sebagaimana tertulis dalam Akta Permohonan Peninjauan Kembali Nomor -/PK/PKPU/2013/PN Niaga Surabaya jo Nomor 01/PKPU/2013/PN Niaga Surabaya. Permohonan tersebut disertai alasan hukum sebagai berikut:

1. Bahwa, Pengurus telah bertindak sewenang-wenang, tidak prosfesional, dan melanggar hukum dikarenakan:

1) Mengakui tagihan PT. Bank Rakyat Indonesia (BRI) Persero, Tbk., dengan rincian pokok utang sejumlah US\$ 10.000.000,00 (sepuluh juta dollar Amerika) atau sebesar Rp. 97.040.000.000,00 (sembilan puluh tujuh miliar empat puluh juta rupiah) dan bunga utang sejumlah US\$ 15.385.605,15 (lima belas juta tiga ratus delapan puluh lima ribu enam ratus lima koma lima belas dollar Amerika) atau sebesar Rp 149.301.912.375,60 (seratus empat puluh sembilan ratus dua belas ribu tiga ratus tujuh puluh lima koma enam puluh rupiah). Padahal tagihan tersebut sudah ditolak oleh Pemohon PK dahulu Termohon PKPU dengan alasan sebagai berikut:

a. Catatan Pembukuan per 5 Maret 2013 yang menerangkan bahwa tagihan Bank BRI terdiri dari utang pokok sebesar US\$ 1.396.903,00 (satu juta tiga ratus sembilan puluh enam ribu sembilan ratus tiga dollar Amerika) dan bunga utang sebesar US\$ 41.282,00 (empat puluh satu ribu dua ratus delapan puluh dua dollar Amerika).

b. Salinan Restated Restructuring Agreement tertanggal 5 Oktober 2007 yang menerangkan adanya pengalihan piutang menjadi saham. Piutang Pemohon PK dahulu Termohon PKPU sejumlah US\$16.802.389.00 (enam belas juta delapan ratus dua ribu tiga ratus delapan puluh sembilan dollar Amerika) dikonversi menjadi saham yang dimiliki Bank BRI 
sebanyak 196.653.620 (seratus sembilan puluh enam juta enam ratus lima puluh tiga ribu enam ratus dua puluh) lembar saham.

2) Menolak tagihan-tagihan dari 7 (tujuh) kreditor sebagaimana telah disebutkan sebelumnya tanpa alasan yang jelas dan tidak berdasar hukum padahal telah diakui oleh Pemohon PK dahulu Termohon PKPU. Para kreditor pun telah mengajukan keberatan kepada Pengurus dan Rapat Permusyawaratan Pemungutan Suara dengan bukti-bukti sebagai berikut:

a. Facility Agreement tertanggal 6 Juli 1995 yang menerangkan bahwa benar Pemohon PK dahulu Termohon PKPU memiliki hutang dari ketujuh kreditor;

b. Sertifikat Hak Tanggungan yang menerangkan bahwa seluruh pinjaman yang diberikan ketujuh kreditor dijaminkan dengan aset-aset milik Pemohon PK dahulu Termohon PKPU.

c. Sertifikat Jaminan Fiducia yang menerangkan bahwa seluruh pinjaman yang diberikan ketujuh kreditor dijaminkan dengan aset-aset milik Pemohon PK dahulu Termohon PKPU.

2. Bahwa, terkait dengan jumlah piutang Bank BRI, Pemohon PK dahulu

Termohon PKPU mengajukan bukti baru atau novum berupa:

1) Surat Nomor SAIP/CS-131207/104 tanggal 13 Desember 2007, yang dikirimkan oleh Pemohon PK dahulu Termohon PKPU kepada PT Raya Saham Registra yang menerangkan piutang PT Bank BRI telah dikonversi menjadi saham sebanyak 129.671.124 (seratus dua puluh sembilan juta enam ratus tujuh puluh satu ribu seratus dua puluh empat) lembar saham di Pemohon PK dahulu Termohon PKPU. Hal ini sekaligus menegaskan kedudukan PT Bank BRI sebagai pemegang saham Pemohon PK dahulu Termohon PKPU.

2) Surat Nomor 005/DIR-RSR/SAI/2007 tanggal 17 Desember 2007, Perihal Nomor Saham atas Pengeluaran Saham Baru PT Surabaya Agung Industri Pulp \& Kertas Tbk., dari PT Raya Saham Registra yang menerangkan Bank BRI merupakan Pemegang Saham atas Pemohon PK dahulu Termohon PKPU sebanyak 129.671.124 saham dengan Nomor Saham 3.320.936.472 sampai dengan 3.450.607.595.

3) Surat Nomor SAIP/CS/X1/05-2011 tanggal 24 November 2011, Perihal Pelaksanaan Penambahan Modal Tanpa HMETD yang dikirimkan oleh Pemohon PK dahulu Termohon PKPU kepada PT Raya Saham Registra yang menerangkan Bank BRI merupakan pemilik saham Pemohon PK dahulu Termohon PKPU dengan jumlah lembar saham sebanyak 66.982.496 (enam puluh enam juta sembilan ratus delapan puluh dua ribu empat ratus sembilan puluh enam).

4) Surat Nomor SAIP/CS/XII/02-2011, tanggal 12 Desember 2011, Perihal 
Pelaksanaan Penambahan Modal Tanpa yang dikirimkan oleh Pemohon PK dahulu Termohon PKPU kepada PT Raya Saham Registra yang menerangkan adanya penambahan modal Pemohon PK dahulu Termohon PKPU dari hasil konversi hutang Bank BRI sebanyak 66.982.496 (enam puluh enam ribu sembilan ratus delapan puluh dua ribu empat ratus sembilan puluh enam) lembar saham dengan nilai Rp66.982.496.000,00 (enam ratus enam puluh enam juta sembilan ratus delapan puluh dua ribu empat ratus sembilan puluh enam ribu) rupiah.

5) Surat Nomor 002/DIR-RSR/SAIP/2011, tanggal 16 Desember 2011, Perihal Penambahan Saham Baru Tanpa HMETD PT Surabaya Agung Industri Pulp \& Kertas Tbk, dari PT Raya Saham Registra kepada PT Bursa Efek Indonesia yang menerangkan adanya penambahan modal Pemohon PK dahulu Termohon PKPU sebagaimana Surat Nomor SAIP/CS/XII/022011, tanggal 12 Desember 2011 (Novum e) bagian dari proses konversi utang menjadi saham;

Terhadap permohonan peninjauan kembali dengan berdasarkan alasan-alasan sebagaimana diuraikan diatas, Majelis Hakim Peninjauan Kembali memberikan pertimbangan hukum, yang pada intinya sebagai berikut:

1. Lembaga PKPU pada dasarnya merupakan instrumen untuk memberikan Debitor kemudahan dan inisiatif untuk mengajukan rencana perdamaian; oleh karena itu adalah wajar jika inisiatif ini dilakukan oleh Debitor kemudahan jika rencana perdamaian ditolak; maka Debitor dinyatakan pailit. Namun situasinya akan berbeda secara philosofis jika yang berinisiatif mengajukan permohonan PKPU adalah Kreditor, seharusnya demi keadilan, setiap PKPU yang diajukan oleh Kreditor yang berakhir dengan ditolaknya rencana perdamaian dan Debitor dinyatakan pailit, kepada Debitor yang bersangkutan harus diberi kesempatan untuk melakukan upaya hukum;

2. Adanya ketentuan Pasal 290 UUK-PKPU pada pokoknya dapat disimpulkan, terhadap pernyataan pailit karena putusan PKPU tidak ada upaya hukum, termasuk upaya hukum PK. Namun demikian ketentuan tersebut, dalam beberapa kasus telah disimpangi melalui putusan PK MA-RI diantaranya Perkara Nomor 145 PK/Pdt.Sus-Pailit/ 2013 tanggal 29 Januari 2014, Perkara Nomor 156 PK/Pdt.Sus-Pailit/2012 tanggal 7 Januari 2013;

3. Alasan-alasan PK dapat dibenarkan karena Pengurus tidak menjalankan tugas dan kewajibannya sesuai dengan ketentuan hukum, bertindak independen in casu Hakim Pengawas yang terbukti bersikap tidak profesional dan proporsional. Hakim Pengawas telah dijatuhi sanksi oleh Mahkamah Agung melalui Ketua Pengadilan Tinggi yang bersangkutan, dimana Hakim Pengawas dalam menangani kasus ini telah melakukan unprofessional conduct;

4. Bukti-bukti peninjauan kembali yang diajukan dapat diterima sebagai novum (bukti baru) yang bersifat menentukan, dan dalam hal ini Pengadilan Niaga pada Pengadilan Negeri Surabaya telah melakukan kekeliruan yang 
nyata.

Ketua Majelis Hakim memberikan dissenting opinion yang pada intinya sebagai berikut:

1. Sesuai ketentuan Pasal 290 Undang Undang Nomor 37 Tahun 2004, yang disimpulkan terhadap pernyataan pailit karena putusan PKPU "tidak ada upaya hukum” termasuk upaya Peninjauan Kembali. Namun Rapat Pleno Kamar tanggal 17 Juli 2014 “disepakati” antara lain: meskipun Pasal 290 UndangUndang Nomor 37 Tahun 2004 tidak dimungkinkan adanya upaya hukum, namun Mahkamah Agung berdasarkan fungsi pengawasan, dapat mengenyampingkan ketentuan tersebut, dengan syarat apabila ditemukan hal yang sangat keliru dalam penerapan hukum oleh Pengadilan sebelumnya;

2. Dari alasan Peninjauan Kembali serta fakta-fakta yang dapat disimpulkan dalam berkas perkara ini, diajukannya upaya hukum didasarkan pada adanya kesalahan penerapan hukum acara. Namun alasan tersebut menurut Ketua Majelis, bukan termasuk "hal-hal yang sangat signifikan" untuk mengenyampingkan Pasal 290 Undang Undang Nomor 37 Tahun 2004 karena alasan Pengawasan Mahkamah Agung, disebabkan:

a. Pertama pihak PT Bank BRI sewaktu voting dilaksanakan ada dalam posisi "absten" sehingga dipandang tidak berpengaruh besar atas pemungutan suara;

b. Kedua masih dimungkinkan dalam "tahap pemberesan" harta pailit bagi kreditor lainnya dapat mengajukan upaya hukum keberatan dalam bentuk "gugatan lain-lain";

c. Dari pertimbangan tersebut di atas, Ketua Majelis berpendapat "permohonan Peninjauan Kembali dinyatakan tidak dapat diterima”.

Majelis Hakim Peninjauan Kembali meskipun terdapat dissenting opinion, terhadap permohonan peninjauan kembali tersebut menyatakan dalam amar putusannya menyatakan:

\section{Mengadili}

1. Mengabulkan permohonan pemeriksaan peninjauan kembali dari Pemohon 
Peninjauan Kembali PT SURABAYA AGUNG INDUSTRI PULP \& KERTAS tersebut;

2. Membatalkan Putusan Pengadilan Niaga pada Pengadilan Negeri Surabaya Nomor 01/PKPU/2013/PN Niaga Sby. tanggal 16 April 2013;

\section{Mengadili Kembali}

1. Menolak permohonan Pemohon PKPU/Pailit;

2. Menghukum Termohon Peninjauan Kembali/Debitor untuk membayar biaya perkara dalam semua tingkat peradilan dan pemeriksaan peninjauan kembali, yang dalam pemeriksaan peninjauan kembali ditetapkan sebesar Rp10.000.000,00 (sepuluh juta rupiah);

\section{Kasus Posisi Putusan Mahkamah Agung Nomor 156.PK/Pdt.Sus/2012}

Heryanto Wijaya selaku pemilik Istana Kopling (selanjutnya disebut sebagai Pemohon) mengajukan permohonan PKPU kepada Firma Litha \& Co. (selanjutnya disebut sebagai Termohon) pada Pengadilan Niaga pada Pengadilan Negeri Makassar. Permohonan tersebut dikarenakan adanya utang sebesar Rp150.219.700,00 ( seratus lima puluh juta dua ratus sembilan belas ribu tujuh ratus Rupiah) ditambah denda sebesar $2 \%$, untuk setiap bulannya, selama 2 (dua) tahun, sehingga total utang Termohon PKPU berdasarkan Putusan Mahkamah Agung Nomor 2051/K/Pdt/2009 tanggal 15 Januari 2010 sebesar Rp222.325.156,00 (dua ratus dua puluh dua juta tiga ratus dua puluh lima ribu seratus lima puluh enam Rupiah). Namun, Pemohon menilai bahwa usaha yang dimiliki oleh Termohon masih mempunyai peluang untuk berkembang karena usaha angkutan Termohon masih berjalan dan tetap melayani rute pengangkutan hingga ke beberapa daerah di Sulawesi Selatan. Selain kepada Pemohon, Termohon memiliki utang kepada PT. Bank Negara Indonesia (BNI) Tbk., (selanjutnya disebut Kreditor Lain I) dan PT. Sumber Indonesia Celluler (selanjutnya disebut sebagai Kreditor Lain II). Adapun utang yang telah jatuh tempo dan dapat ditagih berdasarkan tidak dilaksanakannya Putusan Mahkamah Agung Nomor 2051/K/Pdt/2009 tanggal 15 Januari 2010, bahkan telah mendapatkan Surat Teguran atau Aanmaning dari Pengadilan Negeri Makassar Nomor 20/Eks/2011/ 
PN.Mks jo Nomor 37/Pdt.G/208/PN.Mks tertanggal 01 Agustus 2011.

Setelah putusan tersebut diucapkan, Termohon (selanjutnya disebut sebagai Pemohon PK dahulu Termohon PKPU) mengajukan permohonan peninjauan kembali pada tanggal 11 September 2012 sebagaimana tertulis dalam Akta Pernyataan Permohonan Peninjauan Kembali Nomor 01/PKPU/2012/PN.MKS yang dibuat oleh Panitera Pengadilan Niaga pada Pengadilan Negeri Makassar disertai dengan memori peninjauan kembali. Pemohon (selanjutnya disebut sebagai Termohon PK dahulu Pemohon PKPU) tidak mengajukan kontra memori peninjauan kembali. Adapun alasan permohonan peninjauan kembali, pada intinya sebagai berikut:

1. Terdapat dua upaya hukum yang dilakukan oleh Termohon PK dahulu Pemohon PKPU dan Kreditor Lain I (selanjutnya disebut sebagai Turut Termohon PK I dahulu Kreditor Lain I PKPU) dengan penjelasan sebagai berikut:

1) Termohon PK dahulu Pemohon PKPU masih belum melaksanakan kewajiban hukumya berdasarkan Putusan Mahkamah Agung Nomor 2051/K/Pdt/2009 tanggal 15 Januari 2010 jo Putusan Pengadilan Tinggi Makassar Nomor247/ Pdt/2008/PT.Mks jo Putusan Pengadilan Negeri Makassar Nomor37/ Pdt.G/2008/PN.Mks yang disertai dengan penyitaan barang. Seharusnya Termohon PK dahulu Pemohon PKPU melakukan pelelangan atas barang yang disita untuk pelunasan utang tersebut.

2) Turut Termohon PK I dahulu Kreditor Lain I PKPU telah mengajukan upaya hukum dalam rangka penyelesaian hutang Pemohon PK dahulu Termohon PKPU sebagaimana tersebut dalam Permohonan Lelang Eksekusi atas barang jaminan Pemohon PK dahulu Termohon PKPU. Permohonan tersebut telah ditindak lanjuti dengan melakukan Penyitaan bahkan telah melakukan Pengumuman Lelang.

2. Pengadilan Niaga Pada Pengadilan Negeri Makassar sama sekali telah keliru dalam menerapkan hukum khususnya terhadap perusahaan yang non Badan Hukum. Pemohon PK dahulu Termohon PKPU bukanlah badan hukum sehingga tidak dapat dijadikan pihak dalam perkara PKPU. Seharusnya pengajuan permohonan PKPU atau Permohonan Pailit ditujukan kepada Pesero bukan 
kepada perusahaannya.

3. Putusan tersebut bertentangan dengan asas keseimbangan, asas kelangsungan usaha, dan asas keadilan dikarenakan Majelis Hakim Pengadilan Niaga pada Pengadilan Negeri Makassar tidak mempertimbangkan fakta-fakta sebagai berikut:

1) Kesiapan Pemohon PK dahulu Termohon PKPU untuk melakukan penyelesaian disertai dengan jadwal pembayaran yang jelas, dengan jumlah utang sebesar Rp18.000.000.000,00 (delapan belas miliar Rupiah);

2) $\operatorname{Ada} \pm 2000$ (dua ribu) karyawan akan mengalami pemutusan hubungan kerja dengan adanya putusan Pemailitan yang dilakukan oleh Pengadilan Niaga Makassar tersebut.

3) Adanya perbedaan nilai utang yang dimaksud oleh Turut Termohon PK dahulu Kreditor Lain I dan sampai persidangan selesai tidak ada satu bukti pun yang diajukan oleh Termohon PK dahulu Pemohon PKPU, Turut Termohon PK I dahulu Kreditor Lain I, maupun Turut Termohon PK II dahulu Kreditor Lain II. Bahwa, alasan tersebut dapat dibenarkan oleh karena dalam putusan yang dimohonkan peninjauan kembali, Judex Facti telah melakukan kekhilafan memutus perkara a quo dengan pertimbangan sebagai berikut:

1. Bahwa, sebagai Termohon PKPU adalah FIRMA LITHA \& CO., yang tidak mempunyai legal standing karena FIRMA LITHA \& CO. tidak berstatus badan hukum, sehingga tidak dapat dijadikan subjek hukum sebagai Termohon PKPU;

2. Bahwa, seharusnya yang dapat dijadikan Termohon PKPU adalah pengurus aktif dari FIRMA LITHA \& CO. tersebut;

3. Bahwa, atas dasar hal-hal tersebut dengan tidak mempertimbangkan alasan lainnya dari Pemohon PK dahulu Termohon PKPU, maka Permohonan Peninjauan Kembali dapat dikabulkan dan Putusan Judex Facti harus dibatalkan;

Majelis Hakim Mahkamah Agung setelah membaca alasan peninjauan kembali memutuskan dengan amar putusan:

\section{Mengadili}

1. Mengabulkan permohonan peninjauan kembali dari Pemohon Peninjauan Kembali : FIRMA LITHA \& CO. tersebut; 
2. Membatalkan Putusan Pengadilan Niaga pada Pengadilan Negeri Makassar Nomor 01/PKPU/2012/PN. NIAGA.MKS. tanggal 03 September 2012;

\section{Mengadili Kembali}

1. Menyatakan permohonan PKPU dari Pemohon PKPU: Heryanto Wijaya tidak dapat diterima;

2. Menyatakan Termohon PKPU: FIRMA LITHA \& CO. tidak berada dalam keadaan pailit;

3. Menghukum Termohon Peninjauan Kembali/Termohon PKPU untuk membayar biaya perkara dalam semua tingkat peradilan dan pemeriksaan peninjauan kembali, yang dalam pemeriksaan peninjauan kembali ditetapkan sebesar Rp10.000.000,00 (sepuluh juta rupiah Rupiah);

\section{Analisa Hukum}

Kekuasaan Kehakiman merupakan salah satu cabang kekuasaan yang dianut dalam sistem ketatanegaraan Indonesia disamping cabang kekuasaan eksekutif dan cabang kekuasaan legislatif. Salah satu ciri dari negara hukum yang demokratis yaitu adanya independen dan tidak berpihak. ${ }^{14}$ Pelaksana dari kekuasaan kehakiman yaitu Mahkamah Agung dan badan peradilan di bawahnya beserta Mahkamah Konstitusi. Sebagaimana diatur dalam Pasal 24 ayat (2) Undang-Undang Dasar Negara Republik Indonesia Tahun 1945 yang mengatur kekuasaan kehakiman dilakukan oleh sebuah Mahkamah Agung dan badan peradilan yang berada di bawahnya dalam lingkungan peradilan umum, lingkungan peradilan agama, lingkungan peradilan militer, lingkungan peradilan tata usaha negara, dan sebuah Mahkamah Konstitusi. Dalam menjalankan tugasnya Mahkamah Agung memiliki kewenangan untuk mengadili pada tingkat kasasi, meguji peraturan perundang-undangan di bawah Undang-Undang terhadap Undang-Undang, dan kewenangan lainnya yang diberikan oleh Undang-Undang.

Sistem peradilan di Indonesia menempatkan Mahkamah Agung sebagai pengadilan negara tertinggi yang membawahi empat lingkungan peradilan di

\footnotetext{
${ }^{14}$ Jimly Asshiddiqie, Pengantar Ilmu Hukum Tata Negara Jilid II (Mahkamah Konstitusi Republik Indonesia 2006).[047].
} 
bawahnya yaitu peradilan umum, peradilan agama, peradilan militer dan peradilan tata usaha negara. Setiap lingkungan peradilan mempunyai kewenangan tersendiri. Namun, secara umum alur sistem peradilan Indonesia akan bermuara di Mahkamah Agung. Putusan pengadilan pertama dapat dimohonkan banding kepada pengadilan tinggi dan putusan pengadilan tinggi dapat dimintakan kasasi ke Mahkmah Agung, kecuali Undang-Undang menentukan lain.

Selain mempunyai kewenangan mengadili pada tingkat kasasi, Mahkamah Agung memiliki pula kewenangan untuk melakukan peninjauan kembali terhadap putusan yang telah berkekuatan hukum tetap. Sebagaimana diatur dalam Pasal 24 ayat (1) Undang-Undang Nomor 48 Tahum 2009 tentang Mahkamah Agung yang mengatur terhadap putusan pengadilan yang telah memperoleh kekuatan hukum tetap, pihak-pihak yang bersangkutan dapat mengajukan peninjauan kembali kepada Mahkamah Agung, apabila terdapat hal atau keadaan tertentu yang ditentukan dalam Undang-Undang.

Persyaratan untuk melakukan peninjauan kembali yaitu adanya hal atau keadaan tertentu seperti ditemukannya bukti baru (novum) dan/atau adanya kekeliruan hakim dalam menerapkan hukumya. Sebagaimana diatur dalam Penjelasan Pasal 24 ayat (1) Undang-Undang Nomor 48 Tahun 2009 tentang Kekuasaan Kehakiman yang mengatur yang dimaksud dengan hal atau keadaan tertentu antara lain adalah ditemukannya bukti baru (novum) dan/atau kekhilafan atau kekeliruan hakim dalam menerapkan hukumnya.

Dalam perkara kepailitan, terdapathukum acara khusus yang mengatur mengenai peninjauan kembali sebagaimana diatur dalam Bab IV, mulai Pasal 295 sampai Pasal 298 UUK-PKPU. Permohonan peninjauan kembali dapat diajukan kepada Mahkamah Agung dengan persyaratan adanya bukti baru yang bersifat menentukan pada waktu persidangan sudah ada, namun belum ditemukan dan terdapat kekeliruan yang nyata. Namun dalam permohonan peninjauan kembali tersebut, terdapat pengecualian yaitu kecuali ditentukan lain dalam Undang-Undang ini.

Sebagai pengadilan negara tertinggi, Mahkamah Agung juga memiliki fungsi pengawasan terhadap lingkungan atau badan peradilan di bawahnya. Pasal 32 
Undang-Undang Nomor 3 Tahun 2009 tentang Mahkamah Agung mengatur:

(1). Mahkamah Agung melakukan pengawasan tertinggi terhadap penyelenggaraan peradilan pada semua badan peradilan yang berada di bawahnya dalam menyelenggarakan kekuasaan kehakiman.

(2). Selain pengawasan sebagaimana dimaksud pada ayat (1), Mahkamah Agung melakukan pengawasan tertinggi terhadap pelaksanaan tugas administrasi dan keuangan.

(3). Mahkamah Agung berwenang untuk meminta keterangan tentang halhal yang bersangkutan dengan teknis peradilan dari semua badan peradilan yang berada di bawahnya.

(4). Mahkamah Agung berwenang memberi petunjuk, teguran, atau peringatan kepada pengadilan di semua badan peradilan yang berada di bawahnya.

(5). Pengawasan dan kewenangan sebagaimana dimaksud pada ayat (1), ayat (2), ayat (3), dan ayat (4) tidak boleh mengurangi kebebasan hakim dalam memeriksa dan memutus perkara.

Dalam Putusan Mahkamah Agung Nomor 48 PK/Pdt.Sus-Pailit/2014 dan 156.PK/Pdt.Sus/2012, tidak tepat apabila Majelis Hakim mengesampingkan Pasal 290 UUK-PKPU dikarenakan:

1. Pasal 290 UUK-PKPU mengatur apabila pengadilan telah menyatakan debitor pailit, maka terhadap putusan pernyataan pailit tersebut berlaku ketentuan tentang kepailitan sebagaimana dimaksud dalam Bab II, kecuali Pasal 11, Pasal 12, Pasal 13, dan Pasal 14. Ketentuan tersebut masih berlaku dan sah secara hukum sejak tanggal diundangkan. Sampai saat ini, ketentuan tersebut belum diubah dan/atau diganti dengan ketentuan yang baru. Begitu pula belum ada putusan Mahkamah Konstitusi yang membatalkan ketentuan tersebut.

2. Pasal 295 ayat (1) UUK-PKPU mengatur terhadap putusan hakim yang telah memperoleh kekuatan hukum tetap, dapat diajukan permohonan peninjauan kembali kepada Mahkamah Agung, kecuali ditentukan lain dalam UndangUndang ini. Sehingga, secara jelas dan nyata, bahwa terdapat pengecualian terhadap perkara-perkara tertentu yang oleh Undang-Undang tidak dapat diajukan permohonan peninjauan kembali. Termasuk perkara yang diatur oleh Pasal 290 UUK-PKPU.

3. Melanggar asas kepastian hukum yang merupakan pondasi utama dari suatu negara hukum. Adanya aturan yang menjadi pedoman bertingkah laku dalam 
hidup bermasyarakat dan pelaksanaannya menimbulkan kepastian hukum. ${ }^{15}$ Kepastian hukum mengandung dua pengertian yaitu adanya aturan membuat mnasyarakat mengetahui apa yang boleh dilakukan dan apa yang tidak boleh dilakukan serta melindungi masyarakat dari kesewenang-wenangan pemerintah. ${ }^{16}$ Tanpa kepastian hukum, masyarakat tidak tahu apa yang harus diperbuat dan kemudian menimbulkan keresahan. ${ }^{17}$ Sehingga dengan adanya penyimpangan terhadap Pasal 290 UUK-PKPU menimbulkan ketidakpastian hukum di masyarakat.

4. Terhadap frasa "menimbang, bahwa sesudah putusan yang telah berkekuatan hukum tetap tersebut" yang tertulis dalam Putusan Mahkamah Agung Nomor 48 PK/Pdt.Sus-Pailit/2014, seyogyanya dirubah dengan frasa "menimbang, bahwa sesudah putusan yang telah berkekuatan hukum tetap dan final tersebut". Sebagaimana telah diuraikan sebelumnya bahwa terdapat perbedaan yang mendasar antara berkekuatan hukum tetap dengan final. Putusan berkekuatan hukum tetap diartikan masih terdapat upaya hukum, sedangkan putusan yang final berarti tidak ada upaya hukum lagi terhadap putusan tersebut. Maruarar Siahaan menyatakan ukuran untuk menentukan apakah putusan satu peradilan telah bersifat final dan mempunyai kekuatan hukum mengikat adalah ada tidaknya badan yang berwenang secara hukum meninjau ulang (review) putusan pengadilan tersebut, serta ada tidaknya mekanisme dalam hukum acara tentang siapa dan bagaimana cara peninjauan ulang tersebut dilakukan. ${ }^{18}$

5. Rapat Pleno Kamar tanggal 17 Juli 2014 disepakati antara lain meskipun Pasal 290 Undang-Undang Nomor 37 Tahun 2004 tidak dimungkinkan adanya upaya hukum, namun Mahkamah Agung berdasarkan fungsi pengawasan, dapat mengenyampingkan ketentuan tersebut, dengan syarat apabila ditemukan hal yang sangat keliru dalam penerapan hukum oleh pengadilan sebelumnya. Fungsi

\footnotetext{
${ }^{15}$ Peter Mahmud Marzuki, 'Pengantar Ilmu Hukum' (Kencana Prana Media 2008).[138].

16 ibid.[138].

${ }^{17}$ Sudikno Mertokusumo, 'Mengenal Hukum Suatu Pengantar' (Liberty 2005).[161].

${ }^{18}$ Maruarar Siahaan, Hukum Acara Mahkamah Konstitusi (Mahkamah Konstitusi RI 2006).
} [275]. 
pengawasan yang dilakukan oleh Mahkamah Agung terkait putusan pengadilan sebelumnya kiranya dimaknai dengan adanya upaya hukum banding, kasasi, dan peninjauan kembali apabila Undang-Undang memberikan wewenang untuk itu. Implementasi dari pengoreksian putusan bukan dengan melanggar ketentuan yang sudah ada. Memang benar bahwa hakim bukanlah corong UndangUndang atau les bouches, qui prononcent les paroles de la loi, sehingga hakim harus dapat menggali hukum yang berkembang di masyarakat untuk melakukan penemuan hukum. Namun, kondisi tersebut berlaku apabila aturannya belum ada atau tidak jelas.

6. Terdapat Surat Edaran Mahkamah Agung (SEMA) Nomor 3 Tahun 2015 tentang Pemberlakuan Rumusan Hasil Rapar Pleno Kamar Mahkamah Agung Tahun 2015 Sebagai Pedoman Pelaksanaan Tugas Bagi Pengadilan dalam Praktik Peradilan. Surat Edaran Mahkamah Agung tersebut pada bagian rumusan kamar hukum perdata menyatakan tidak ada upaya hukum terhadap Putusan PKPU Tetap tidak disetujui oleh kreditor, kemudian debitor dinyatakan pailit sebagaimana diatur dalam Pasal 290. Jika terhadap putusan kepailitan/PKPU yang tidak tersedia upaya hukum apapun sebagaimana dimaksud dalam huruf b di atas tetap diajukan ke MA, maka isi amar putusan adalah tidak dapat diterima.

Berdasarkan uraian tersebut, Mahkamah Agung tidak memiliki kewenangan untuk menerima permohonan peninjauan kembali dalam perkara yang sesuai dengan Pasal 290 UUK-PKPU. Ketentuan tersebut secara hukum masih sah dan berlaku. lex dura, sed tamen scripta (Undang-Undang itu kejam, tetapi memang demikianlah bunyinya). Sehingga Mahkamah Agung memiliki kewajiban untuk menegakkan aturan tersebut. Fiat justitia et pereat mundus (meskipun dunia ini runtuh, hukum harus ditegakkan).

\section{Kesimpulan}

Putusan Pailit yang didahului dengan PKPU bersifat final sehingga tidak ada upaya hukum lain yang dapat dilakukan sebagaimana diatur dalam Pasal 290 UUK-PKPU. Majelis Hakim dalam Putusan Mahkamah Agung No. 48.PK/Pdt.Sus- 
Pailit/2014 dan No. 156.PK/Pdt.Sus/2012 telah melakukan penyimpangan hukum terhadap ketentuan Pasal Pasal 290 UUK-PKPU.

Majelis Hakim dalam Putusan Mahkamah Agung No. 48.PK/Pdt.SusPailit/2014 dan No. 156.PK/Pdt.Sus/2012 seharusnya meminta kepada pemohon peninjauan kembali untuk melakukan judicial review Pasal 290 UUK-PKPU kepada Mahkamah Konstitusi sehingga tidak terjadi penyimpangan hukum.

\section{Daftar Bacaan}

\section{Buku}

Jimly Asshiddiqie, Pengantar Ilmu Hukum Tata Negara Jilid II (Mahkamah Konstitusi Republik Indonesia 2006).

M. Hadi Subhan, Hukum Kepailitan; Prins.Ip, Norma, Dan Praktik Di Peradilan (Kencana Prenada Media 2008).

Maruarar Siahaan, Hukum Acara Mahkamah Konstitusi (Mahkamah Konstitusi RI 2006).

Peter Mahmud Marzuki, Pengantar Ilmu Hukum (Kencana Prana Media 2008).

Peter Mahmud Marzuki, Penelitian Hukum (Kencana Prenada Media 2014).

Sudikno Mertokusumo, Mengenal Hukum Suatu Pengantar (Liberty 2005).

Sutan Remy Sjahdeini, Hukum Kepailitan: Memahami Undang-Undang Nomor 37 Tahun 2004 Tentang Kepailitan (Pustaka Utama Grafiti 2009).

Sultan Reny Sjahdeini, Sejarah, Asas, Dan Teori Hukum Kepailitan, Memahami Undang-Undang Nomor 37 Tahun 2004 Tentang Kepailitan Dan Penundaan Kewajiban Pembayaran Utang (Kencana Prenada Media 2016).

Victor Simamorang dan Hendri Sukarso, Pengantar Hukum Kepailitan Di Indonesia (Rineka Cipta 1994).

Zainal Asikin, Hukum Kepailitan Dan Penundaan Pembayaran Di Indonesia (Raja Grafindo Persada 2001).

\section{Putusan}

Putusan Mahkamah Konstitusi Nomor: 071/PUU-II/2004 dan Nomor: 001-002/ PUU-III/2005.

HOW TO CITE: Muhammad Pasca Zakky Muhajir Ridlwan, 'Penyimpangan Bentuk Upaya Hukum Terhadap Putusan Pailit Akibat PKPU Gagal' (2019) Vol. 2 No. 1 Notaire. 